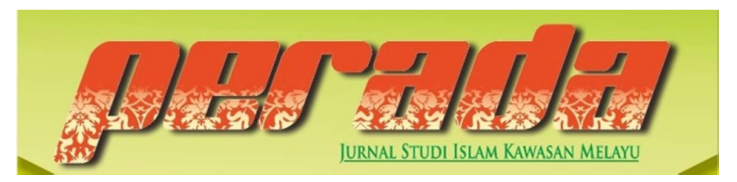

Perada: Jurnal Studi Islam Kawasan Melayu

ISSN 2656-7202 (P) ISSN 2655-6626 (0)

Volume 3 Nomor 2, Juli-Desember 2020

DOI: https://doi.org/10.35961/perada.v3i2.206

\title{
IMPLEMENTASI PEMBERANTASAN BUTA HURUF ARAB (AL- QUR'AN) DENGAN METODE TARSANA PADA PELAJAR SEKOLAH DASAR DI KECAMATAN CIGUDEG
}

\author{
Irman Sumantri \\ Sekolah Tinggi Agama Islam Darunnajah Bogor \\ irmansumantri11@gmail.com
}

\begin{abstract}
ABSTRAK
Penelitian ini bertujuan untuk menemukan kondisi implementasi metode Tarsana dalam pemberantasan buta huruf arab (al-Qur'an) pada siswa sekolah dasar di kecamatan Cigudeg kabupaten Bogor. Metode penelitian deskriftif kuantitatif dengan instrument data observasi dan kuesionaer. Hasil penelitian menunjukkan bahwa 1) guru belum mengimplementasikan metode Tarsana pada siswanya secara rutin, sehingga menyebabkan banyak siswanya yang kurang mahir dalam memabaca dan menulis al-Qur'an; 2) ada beberapa hambatan yang dihadapi guru dalam pelaksanaan metode Tarsana baik secara internal maupun secara eksternal. Penelitian ini merekomendasikan kepada peneliti selanjutnya untuk mendesain pembelajaran baca tulis alQur'an yang baru, bervariasi dan dapat menumbuhkan minat serta motivasi anak dalam belajar untuk ketercapaiannya visi misi kabupaten Bogor.
\end{abstract}

This study aims to find the conditions for the implementation of the Tarsana method in the eradication of Arabic illiteracy (al-Qur'an) in elementary school students in the Cigudeg subdistrict, Bogor district. Quantitative descriptive research method with observational data instruments and questionnaires. The results showed that 1) the teachers had not implemented the Tarsana method on their students regularly, causing many students to be less proficient in reading and writing the Qur'an; 2) there are several obstacles faced by the teacher in implementing the Tarsana method both internally and externally. This study recommends the next researchers to design learning to read and write al-Qur'an that is new, varied, and can foster children's interest and motivation in learning to achieve the vision and mission of Bogor district.

Kata kunci: Metode Tarsana, Buta Huruf, Al-Qur'an 


\section{PENDAHULUAN}

Semua umat Islam di pelosok dunia mengetahui bahwa al-Qur'an kalamullah yang dikabarkan kepada Nabi dan rasul dengan penghubungnya malaikat Jibril secara berangsur-angsur. Kitab suci ini merupakan sebagai hukum dan pedoman utama untuk melaksanakan aktivitas kehidupan agar mencapai kebahagiaan dkeduniaan dan akhirat. Namun untuk mempelajari dan memahami al-Qur'an yang jumlahnya 30 juz diperlukan kecakapan dalam memahami huruf-huruf dasar hijaiyah. Maka dari itu belajar membaca alQur'an merupakan suatu kewajiban bagi semua umat Islam diseluruh pelosok dunia.

Berdasarkan hasil riset Institut Ilmu Al-Qur'an (IIQ) bahwa sekitar 65 persen masyarakat Indonesia buta huruf Al-Qur'an. Meski umat Islam masih mayoritas di Indonesia, kondisinya memprihatinkan, terutama dalam hal kemampuan membaca Al-Qur'an. ${ }^{1}$ Dari sekitar 225 juta Muslim, sebanyak $54 \%$ di antaranya termasuk kategori buta huruf Al-Qur'an. Berdasarkan data Susenas yang dihimpun oleh BPS tahun 2018, sebanyak 53,57\% penduduk muslim di Indonesia belum bisa membaca Al-Qur'an . Hal ini membuat UNESCO, UNICEF, WHO, World Bank dan Human Right Watch merasa prihatin dengan kondisi yang demikian. ${ }^{2}$

Hal ini menjadi polemic dimasyarakat khususnya kementrian agama yang bertang-

\footnotetext{
${ }^{1}$ Sarnapi, Ironis, 54\% Muslim Indonesia Tak Bisa Baca Alquran, 2017, https://www.pikiranrakyat.com/nasional/pr-01290792/ironis-54-muslimindonesia-tak-bisa-baca-alquran-

415880\#: :text=Dari sekitar 225 juta Muslim,buta huruf Alquran perlu digalakkan. (accessed 21 Agustus 2020)

2 Singgih Kuswardono, Zukhaira, Pengembangan Karakter Masyarakat (Development of Character Community) Melalui Penuntasan Buta Aksara Al-Qur'an Dengan Metode Yanbua, Jurnal Abdimas, 18.2 (2014), 116
}

gung jawab untuk menyelesaikannya. Padahal setiap guru disekolah umum, madrasah dan dipengajian sering membimbing dan memerintahkan muridnya untuk mengaji. Dalam hal ini pemerintah memberikan himbauan yang tertuang dalam INPRES Nomor 1 Tahun 1994 dan Nomor 5 tahun 2006 bahwa pembelajaran untuk tingkat dasar minimal selama 9 tahun guna mengurangi buta huruf. Ini merupakan Langkah kongkrit pemerintah dalam rangka pemberantasan buta huruf dan wajib mengikuti pelajaran bagi masyarakat. Agama Islam terus menerus memotivasi agar menjelma umat yang beradab, salah satunya dimulai dengan hal yang kecil seperti belajar membaca huruf hijaiyah dan bisa dilanjutkan dengan melafalkan surah-surah pendek serta akan menambah pengetahuan.

Di kabupaten Bogor dalam rangka memberantas buta huruf al-Qur'an sudah masuk dalam program pemerintah Bogor ngaos yang dipertimbangkan menjadi kurikulum. Hal ini juga dijabarkan dalam visi kabupaten Bogor "Terwujudnya Masyarakat Kabupaten Bogor yang Bertaqwa, Berdaya dan Berbudaya Menuju Sejahtera." Selanjutnya dalam misinya disebutkan "Meningkatkan Kesolehan Sosial Masyarakat dalam Kehidupan Kemasyarakatan.” Untuk menyetak kader agar sesuai visi misi kabupaten Bogor, maka dimulai pada Pendidikan dasar dengan pemberantasan buta huruf arab. Hal ini dilakukan agar masyarakat kedepannya mempu memahami al-Qur'an dan menciptakan masyarakat Bogor beradab.

Hal tersebut tertuang dalam program panca karsa yaitu Bogor Cerdas, Bogor Sehat, Bogor Maju, Bogor Membangun, serta Bogor Berkeadaban. ${ }^{3}$ Selain itu juga

3 Kurnia, Program Pancakarya Antarkan Kabupaten Bogor jadi Kabupaten Terinovatif, 2019, https:/ /galamedia.pikiran-rakyat.com/news/pr- 
untuk mencetak masyarakat berkeadaban, maka ade yasin selaku bupati meluncurkan program Bogor ngaos. Program ini masih dalam proses pertimbangan agar masuk dalam kurikulum setiap sekolah. Tetapi meskipun belum masuk dalam kurikulum sekolah, Bupati Kabupaten Bogor Ade Yasin telah mengintruksikan kepada dinas pendidikan dan kementrian agama kabupaten Bogor untuk mengimplementasikan serta mengsosialisasikan program tersebut kepada setiap sekolah. ${ }^{4}$ Entis Sutisna selaku kepala dinas Pendidikan menyebutkan bahwa program Bogor Ngaos bukan hanya kegiatan yang dilakukan secara rutin setiap hari Jumat di sekolah se-Kabupaten Bogor. ${ }^{5}$

Tetapi program ini dilaksanakan selama 30 menit setiap hari Jum'at pagi, tepatnya sebelum kegiatan belajar mengajar dimulai dan dibimbing oleh guru. Kegiatan ini merupakan antisipasi untuk mengurangi kegiatan-kegiatan siswa dalam mengurangi kenakalan remaja. Hal ini bertujuan agar siswa memiliki pondasi nilai-nilai agama yang semakin kokoh. Apabila hal ini ditanamkan sejak dini, maka kedepannya akan mengatasi kenakalan remaja. Banyak ditemukan kenakalan-kenakalan gara-gara tingkah laku para remaja. Mereka melakukan kenakalan-kenakalan tanpa adanya iman dan

35541439/program-pancakarya-antarkan-kabupatenbogor-jadi-kabupaten-terinovatif, (accessed 21 Agustus 2020)

${ }^{4}$ Ratna Puspita, Disdik Bogor Rencanakan Program Baca Tulis Alquran, 2019, https://www.republika.co.id/berita/duniaislam/wakaf/pn2hsp423/nasional/jabodetabeknasional/19/02/10/pmpsza428-disdik-bogorrencanakan-program-baca-tulis-alquran, (accessed 21 Agustus 2020)

5 M Fikri Setiawan, Bupati Bogor dengan 2.500 siswa khataman Al Quran sambut tahun baru, 2019 ,

https://www.antaranews.com/berita/1229703/bupa ti-bogor-dengan-2500-siswa-khataman-al-quransambut-tahun-baru, (accessed 21 Agustus 2020) nilai-nilai agama yang begitu kuat melekat pada diri setiap insan. Akan tetapi program tersebut masih belum efektif, karena masih ditemukan sekolah-sekolah yang kurang dalam merespon program pemerintah tersebut.

Hal ini memerlukan pemikiran dan penjelasan yang mendalam guna memecahkan masalah yang dialami oleh setiap sekolah. Dalam paper ini penulis mengupas tentang (1) faktor internal dan eksternal yang menghambat buta aksara alQur'an di Sekolah dasar; (2) implementasi metode Tarsana dalam menurunkan angka buta aksara al-Qur'an. Oleh karena itu penulis terpanggil untuk mengangkatnya kedalam pengabdian masyarakat dengan judul "Implementasi pemberantasan buta huruf arab (al-Qur'an) dengan metode Tarsana pada pelajar sekolah dasar Di kecamatan Cigudeg”.

\section{KAJIAN TEORI}

Pada jenjang sekolah dasar membaca, menulis ayat-ayat al-Qur'an merupakan suatu kompetensi inti yang mendasar mesti dimiliki oleh siswa. Banyak metode-metode pembelajaran untuk menunjang dalam mencapai kompetensi tersebut. Implementasi pemberantasan buta huruf arab (alQur'an) suatu prosedur yang melibatkan pelaksanaan metode pembelajaran dalam pemberantasan buta huruf Al-Qur'an dengan tujuan tertentu kepada anak didik. Metode pembelajaran berhubungan erat dengan pemilihan strategi dan pembuatan struktur keterampilan, dan aktivitas anak didik. ${ }^{6}$ Metode adalah seperangkat cara, jalan dan mekanisme yang harus digunakan oleh

${ }^{6}$ Sadiah, Implementasi Model Pembelajaran Dalam Pemberantasan Buta Huruf Alquran Di Majelis Taklim Nurul Hikmah Kampung Situ Uncal Desa Purwasari Kecamatan Dramaga Kabupaten Bogor, Prosiding Al Hidayah: Pendidikan Agama Islam, (2018), 4. 
pendidik. Sebagai usaha untuk menyampaikan pendidikan dan pengajaran kepada peserta didik agar mencapai maksud pendidikan yang termuat dalam kurikulum yang telah ditetapkan. ${ }^{7}$ Sedangkan menurut Omar Mohammad Al-Touny As-Syaibany, bahwa metode mengajar bermakna segala kegiatan yang terarah yang dikerjakan oleh guru dalam rangka kemestian-kemestian mata pelajaran yang diajarkannya, ciri-ciri perkembangan muridnya, keadaan alam sekitarnya dan bermaksud untuk menolong anak didiknya dalam mencapai proses belajar yang diharapkan dan perubahan yang dikehendaki pada tingkah laku mereka. ${ }^{8}$

Ciri utama sebuah metode pembelajaran adalah adanya tahapan-tahapan dan perubahan pembelajaran yang lebih bermakna serta berkelanjutan. Metode yaitu pola atau perencanaan yang didisain untuk menciptakan pembelajaran dikelas berhasil dan berdayaguna untuk mencapai maksud yang diharapkan. Apabila metode tersebut dihubungkan dengan pendidikan Islam, maka metode dalam perspektif Islam ialah sebagai jalan pembaharuan keterampilan, sikap dan perilaku agar menjadi pribadi yang Islami. Selanjutnya Abudin Nata mengemukakan bahwa metode dapat diartikan sebagai cara untuk menginterpretasikan dan menguraikan ajaran Islam, sehingga terus meningkat perkembangan sesuai zamannya. Metode mengajar perlu dimiliki dan dipahami oleh pendidik, karena kesuksesan pengajaran bergantung pada cara guru menyampaikan materi pembelajarnya. Jika cara mengajar yang dilakukan oleh gurunya menyenangkan menurut siswa, maka siswa

7 Ramayulis, Ilmu Pendidikan Islam, (Jakarta: Kalam Mulia, 2004), h. 155-156.

8 Omar Mohammad Al-Toumy As-Syaibany, Falsafah Pendidikan Islam, (Jakarta: Bulan Bintang, 1979), h. 553.

9 Abudin Nata, Filsafat Pendidikan Islam, (Jakarta: Logos Wacana Ilmu, 2001), h. 91. akan tekun, rajin, termotivasi, terangsang, menarik minat, dan antusias siswa dalam menerima pelajaran yang disampaikan dengan optimal. Adapun metode yang bisa dipakai oleh pendidik dalam mengajarkan baca tulis al-Qur'an diantaranya adalah metode pembiasaan, sorogan, latihan, iqra, hafalan, keteladanan, dan Tarsana.

Metode Tarsana disusun oleh $\mathrm{KH}$. Sjamsudin Mustaqim yang secara kelembagaan didirikan pada tahun 2005 di kabupaten Ngawi Jawa Timur yang terdiri dari dua jilid. Tarsana yaitu singkatan dari Tartil (sesuai tajwid), Sar'i (Cepat), Nagham (lagu), metode ini dapat cepat dikuasai oleh para peserta didik dengan sistem tujuh jam. ${ }^{10}$ Metode ini menggabungkan ketiga konsep tersebut untuk memudahkan pelafalan huruf-huruf dan mudah untuk dihafalkan atau diingat. Metode belajar Tarsana yaitu mengucapkan huruf-huruf beserta makharijul buruf-nya dengan keras dan menggunakan lagu. Ciri metode ini yaitu menggunakan nagham (lagu) dalam pembelajarannya. Sehingga peserta didik merasa tertarik untuk mempelajarinya serta tidak mereasa cepat bosan dan jenuh. Metode ini sangat cocok digunakan kepada siswa sekolah dasar, karena siswa di usia sekolah dasar sangat menyukai lagu. Maka dari itu penyampaian materinya bisa dikombinasikan dengan lagu yang menggunakan metode Tarsana (tartil, sar'i, dan nagham).

Tartil merupakan sebuah aturan dalam pembacaan Al-Qur'an secara lembut dengan tajwid dan makhraj yang tegas dan benar. Menurut Ade Yasin, bahwa tartil adalah membaca dengan jelas dan tenang, mengeluarkan huruf dari makhrojnya dengan memberikan sifat asli maupun sifat yang berubah serta memperhatikan makna ayat.

10 Syamsudin Mustaqim. Bimbingan Belajar Membaca Al-Qur'an TARSANA. (Ngawi: CV. Mahardhika, 2005). 
"Lebih spesifiknya, membaca tartil adalah membaca dengan tidak terburu-buru". ${ }^{11}$

Tartil termasuk kedalam metode pembelajaran yang bertujuan untuk membantu siswa agar dapat belajar alQur'an dengan cepat dan tepat. ${ }^{12}$ Lebih lanjut bahwa tartil yaitu metode belajar alqur'an dengan secara perlahan agar pembaca dan pendengar bisa memahami kandungan al-Qur'an yang dibacanya. Tartil merupakan aturan mem-baca al-Qur'an dengan tidak terburu-buru, sehingga hukum bacaan tajwidnya jelas (tidak samar) satu persatu. Untuk membaca al-Qur'an dengan tartil maka dibutuhkan pengetahuan dan pemahaman tentang huruf-huruf hijaiyah beserta makharijul hurufnya. Agar pembaca bisa memahami aturan-aturan dalam membaca al-Qur'an maka dianjurkan untuk mengetahui tentang tajwid. Di dalam kaidah ilmu tajwid ada beberapa bacaan yang mengandung mad (panjang), ghunnah, ikhfa, iqlab, idzhar, idghom serta yang lainnya. Ilmu tajwid adalah ilmu yang mendalami tentang tata cara pelafalan huruf hijaiyah dengan benar dan jelas sesuai dengan aturan yang berlaku. ${ }^{13}$

Membaca al-Qur'an dengan tartil akan sangat mempengaruhi jiwa pembacanya dan bisa membuat tenang batin dan bacalah $\mathrm{Al}$ Quran itu dengan perlahan-lahan (Q.S. Al-

\footnotetext{
11 Ratna Puspita, Disdik Bogor Rencanakan Program Baca Tulis Alquran, 2019, https://www.republika.co.id/berita/duniaislam/wakaf/pn2hsp423/nasional/jabodetabeknasional/19/02/10/pmpsza428-disdik-bogorrencanakan-program-baca-tulis-alquran, (accessed 21 Agustus 2020)

${ }^{12}$ Syafrimen Syafril dan Nova Erlina Yaumas, Penggunaan Metode Tartil dalam Meningkatkean Kemampuan Membaca al- Qur'an Mahasiswa IAIN Raden Intan Lampung Indonesia, Jurnal Pendidikan, 2012.

13 Qosim Arsadani, Qiraah Alquran Dengan Nagham Ajam - Lagam Jawa; Kasus Isra' Mi'raj di Istana Negara, SALAM: Jurnal Sosial dan Budaya Syar-I, 3.1, (2016), 105.
}

Muzammil: 4). dan Kami membacanya secara tartil (teratur dan benar) (Al-Furqan: 32). Sesungguhnya setiap anak adam yang membaca al-Qur'an dengan terburu-buru maka dia hanya akan mendapatkan tujuan membaca saja, tidak mendapatkan pahala keutamaan membacanya. Oleh sebab itu, dalam membaca al-Qur'an dianjurkan untuk tartil, makhorijul hurufnya pas, dan hukum tajwidnya juga digunakan.

Sar'i artinya cepat. Karena dalam metode Tarsana dimulai dengan pengenalan huruf dasar satu persatu yang diucapkan oleh guru kemudian diikuti oleh semua siswanya, di situ otak kiri bekerja. Selain itu juga dengan mengajarkan satu persatu huruf, maka guru menjelaskan makhorijul huruf. Karena masih banyak ditemukan pelafalan huruf-huruf masih ada yang tertukar. Makhorijul huruf merupakan tempat-tempat dimana keluarnya huruf-huruf hijaiyah. Dengan begitu siswa akan lebih memahami dan hafal satu persatunya huruf hijaiyah. Hal ini dilakukan agar siswa bisa menggerakkan otak kanan dan otak kiri dengan memberikan irama lagu Al-Quran pada huruf-huruf yang dibaca. Dengan begitu, para siswa lebih gampang mengenal dan menghafal huruf-huruf hijaiyah dan sekaligus belajar lagu Al Quran dengan cepat dan benar.

Nagham artinya nyayian atau irama dengan variasi nada suara yang teratur dan harmonis tanpa menyalahi hukum-hukum bacaan tajwid. Maka pembelajaran al-qur'an menjadi semakin menarik dan menyenangkan bagi siswa. Nagham bisa disebut juga sebagai lagu atau melodi yang ber-ta'rif sebagai vokal suara indah tunggal tanpa diiringi alat musik dan hanya di gunakan untuk memperindah bacaan Al-Qur'an. ${ }^{14}$

${ }^{14}$ Ainatu Masrurin, Resepsi alquran dalam tradisi pesantren di Indonesia (studi kajian nagham alquran di pondoke pesantren tarbitayul quran ngadiluweb kediri), Al- 
Secara umum bahwa nagham merupakan pembacaan ayat-ayat al-Qur'an dengan lagu dengan berbagai variasi dan nada tanpa menyalahi hukum ilmu tajwid. ${ }^{15}$ Dengan demikian bahwa nagham merupakan bentuk ekspresi seni pembaca dalam membaca alQur'an. Nagham bersumber dari tradisi kebudayaan bangsa arab yang kemudian dikembangkan di Indonesia dengan tujuan untuk memperindah tilawah al-Qur'an.

Secara umum Nagham ada delapan jenis yaitu Bayyati (Husaini), Sika, Shoba (Maya), Rasta alan nawa, Hijazi (Hijaz), Jiharkah, Nahawarand (Iraqi), dan Banjaka (Rakbi). Dalam membaca dan melagukan dengan nada yang begitu sangat merdu hukumnya bisa menjadi haram. Apabila para pembaca tidak memperhatikan hubungan antar huruf, temapt keluarnya huruf, dan sifatul huruf yang telah dianjurkan dalam ilmu tajwid. Nagham digunakan untuk memperindah suara pembaca dalam membaca al-Qur'an. Sebagaimana sabda Nabi Muhammad saw; Hiasilah al-Qur'an dengan suaramu (HR. Abu Daud). Nabi juga sangat menganjurkan dalam haditsnya Bukanlah termasuk golonganku barang siapa yang tidak melagukan al-Qur'an. (HR. Abu Daud). Adapun nagham dalam penerapan metode Tarsana ini menggunakan lagu Rasta alan nawa, karena sangat mudah dalam pengucapan sehingga siswa mudah untuk menirukan apa yang dibaca oleh gurunya tersebut.

Membaca al-Qur'an merupakan suatu aktifitas yang dilakukan oleh individu untuk melihat, mengeja, melafadzkan dan memahami isi yang dibacakan tersebut. Al-Qur'an

Bayan: Jurnal Studi Ilmu Al- Qur'an dan Tafsir, 3.2, (2019), h.105.

15 Muhammad Aminullah, Nagham Al-Qur'an Dalam Masyarakat Bima, PROCEEDINGS ANCOMS $20171^{\text {st }}$ Annual Conference for Muslim Scholars Kopertais Wilayah IV Surabaya, (2017), h. 535 merupakan akar segala ilmu dan sebagai sebuah pedoman dalam melaksanakan kehidupan untuk meraih keselamatan di dunia dan alam akhirat. Setiap muslim yang membaca al-Qur'an akan mendapatkan ganjaran yang tidak terhingga dari Allah swt. Keutamaan-keutamaan dalam membaca AlQur'an di antara:

a. Sebagai pemberi manfaat bagi pembacanya kelak di hari kiamat.

b. Sesuai dengan Allah SWT akan meninggikan dan memuliakan derajat orang yang gemar membaca Al-Qur'an.

c. Akan memperoleh ganjaran dan dilipat gandakan ganjaran itu.

d. Sebagai penyejuk bagi yang pembaca.

e. Akan bergabung dengan para malaikat Allah. ${ }^{16}$

Dengan adanya janji Allah yang disampaikan kepada setiap muslim pembaca al-Qur'an, maka akan mempunyai semangat dan giroh yang akan lebih ditingkatkan lagi. Apabila siswa sudah lancar dan fasih dalam membaca al-Qur'an, maka siswa telah mencapai kecerdasan spiritual yang berhubungan dengan hati, maka akan mencapai kesuksesan di dunia dan di akhirat yang didasari dengan kekuatan iman kepada Allah swt. Sesuai janji Allah swt dan Rasulnya bahwa setiap muslim yang gemar membaca al-Qur'an maka dia mendapatkan balasan yaitu surganya Allah.

\section{METODE TARSANA DAN EFEK- TIFITAS PEMBELAJARAN BACA AL- QUR'AN}

Belajar membaca al-Qur'an dengan metode Tarsana lebih mudah menerapkannya kepada siswa yang jumlahnya banyak. Selain itu juga metode ini sangat

16 Al-Imam Abu Zakaria Yahya bin Syaraf anNawawi, Riyadhus Sholibin, Penerjemah. Achmad Sunarto (Jakarta. Pustaka Amani, 1999), cet.IV h. 115-119. 
menarik perhatian siswa karena menggunakan nagham atau lagu yang mudah diucapkan. Harapan dari metode ini siswa lebih mudah membedakan, mengetahui, memahami dan melafalkan huruf-huruf sesuai makhorijul hurufnya. Dengan begitu, kemampuan siswa dalam membaca alQur'an akan meningkat dan bisa memahami makna dari ayat-ayat yang dibacanya.

Buku Tarsana terdiri dari 2 jilid, jilid pertama terdiri dari 8 halaman. Adapun isi perhalamannya yaitu halaman 1 dan 2 pengenalan huruf putus dan sambung dengan harakat fathah. Halaman 3 pengenalan dengan harakat kasrah dan dhammah. Halaman 4 pengenalan mad (Panjang). Halaman 5 pengenalan sukun dan tasydid. Halaman 6 pengenalan harakat dobel (tanwin) dan waqaf. Halaman 7 pengenalan al syamsiah dan al qamariyah serta mad (Panjang). Halaman 8 pengenalan tentang tajwid sederhana. Tajwid yang diajarkan dalam metode Tarsana di antaranya:

1. ج ج $\diamond$ \& dibaca jelas tanpa mendengung.

2. dibaca tasydid tanpa mendengung.

3. نُ نْ نْ مُ وْ dibaca tasydid dan mendengung.

4. $\stackrel{\mathscr{S}}{=} / \stackrel{\circ}{ }$ yang bertemu dengan selain itu dibaca samar dan mendengung ( ب ت (ج د ذ ز س ش ص ض ط ط ف ق ك )

5. نّ dan jangan lupa baca mendengung

6. Apabila ada harus dibaca dengan mendengung.

7. Apabila ada ’̊ yang bertemu selain itu dibaca jelas tanpa mendengung.

Agar penggunaan metode Tarsana dapat berjalan maksimal dan efisien, maka ada beberapa tahapan pembelajaran pada jilid 1 diataranya;

1. Pengenalan huruf hijaiyah dan cara menyambung huruf hijaiyah dengan harakat fathah. Guru memberikan contoh sesuai dengan makharijul huruf yang benar tanpa dilagukan terlebih dahulu.

2. Setelah dikenalkan dengan baris ke 1, siswa dikenalkan dengan bentuk huruf sambung sesuai dengan makharijul huruf yang benar tanpa dilagukan.

3. Sebelum siswa memahami dan menguasai halaman 1, maka tidak diperkenankan dilanjutkan pada halaman 2 dan selanjutnya.

4. Halaman 1-3 dibiasakan membaca pendek karena belum diperkenalkan tanda Panjang. Apabila siswa membaca Panjang maka guru harus menegurnya dan dibetulkan kesalahannya agar tidak menjadi kebiasaan.

5. Halaman 4 pengenalan mad dengan membaca tanpa mad tetapi tetap dibaca pendek.

6. Halaman 5 pengenalan sukun, tasydid dan qolqolah dengan diberi contoh oleh guru kemudian dilagukan.

7. Pada halaman 4 dan 5 merupakan rawan, karena guru dan siswa dituntut untuk sabar, tanah dan berhati-hati dalam pengucapan makhraj dan hukum bacaan tajwidnya.

8. Halaman 6 pengenalan tanwin dan waqaf dengan cara penyampaiannya kepada siswa dengan dilagukan.

9. Halaman 7 pengenalan al dan mad far'I serta sudah dikenalkan kalimat-kalimat pendek dalam al-Qur'an.

10. Halaman 8 pengenalan tajwid dengan dilagukan. Pada halaman ini siswa diwajibkan untuk menghafal dan tatacara membacanya dengan baik dan benar.

Apabila siswa belum menguasi pada setiap tahapan, maka tidak diperkenankan untuk melanjutkan pada tahapan selanjutnya atau dilanjutkan pada jilid 2. Ada beberapa 
catatan yang harus di ingat-ingat seperti menguasai tajwid yang tertera dalam jilid 1 dengan jelas dan tepat. Apabila jilid 1 sudah bisa dikuasai oleh siswa maka bisa melanjutkan pada jilid 2. Pada jilid ini terdiri dari 8 halaman, adapun cara pembelajaran pada tahap ini di antaranya;

1. Sebelum memulai Latihan membaca, maka siswa harus mengucapkan tajwid terlebih dahulu. Ini sangat dianjurkan hafal mulai dari nomor 1-7.

2. Terapkan tajwid dengan dibimbing oleh guru.

3. Perhatikan bacaan dengan jelas agar semua yang dibaca harus tepat dan benar sesuai makhraj dan hukum tajwid.

4. Tanda strip (-) dibaca lengkap sampai harakat terakhir, tanda lingkaran (o) dibaca waqaf (berhenti) sesuai dengan ketentuan waqafnya.

5. Bisa dibaca dengan lagu Rosta dan bisa juga dengan lagu Rosta'alan nawa atau zanjiron.

6. Dibaca dengan suara yang lantang sesuai dengan kebutuhan dan kemampuan yang dimiliki.

Tujuan metode Tarsana merupakan suatu cara menjembatani siswa yang secara umum belum bisa membaca al-Qur'an dengan baik sesuai makhraj dan kaidah tajwid. Setiap metode mempunyai kelebihan dan kekurangannya, secara umum kelebihan metode Tarsana yaitu memudahkan bagi para siswa untuk belajar al-Qur'an dengan waktu yang begitu singkat serta mengasikkan. Sedangkan kekurangannya yaitu apabila ditemukan siswa yang belum mahir membaca al-Qur'an dan belum bisa mengikuti gurunya untuk melagukan maka orang tersebut akan tertinggal materi selanjutnya. Namun untuk mengantisipasi terjadinya hal yang demikian, alangkah baiknya pembelajaran dengan metode ini dibagi menjadi beberapa kelompok kecil.
Dengan seperti itu akan terlihat kemampuan siswa dalam membaca al-Qur'an dan diberikan bimbingan khusus agar tidak ketinggalan materi.

Berdasarkan hasil yang didapatkan dilapangan bahwa dari 55 jumlah sekolah dasar yang ada dilingkungan dinas Pendidikan kecamatan cigudeg, hanya 10 sekolah yang sudah menerapkan metode Tarsana yang dianjurkan oleh bupati melalui kordinator Pendidikan kecamatan. Sedangkan 45 sekolah lagi belum bisa mengimplementasikan metode Tarsana dengan berbagai faktor. Keberhasilan proses pembelajaran sedikit banyaknya dipengaruhi oleh beberapa faktor penunjang. Adapun beberapa faktor yang dapat mewariskan kontribusi besar pada keberhasilan metode pembelajaran yaitu: faktor jasmaniah (gangguan kesehatan, cacat tubuh, penglihatan, dan pendengaran), faktor faktor psikologis (tingkat intelegensi, sikap, minat, bakat, dan motivasi siswa), faktor sekolah (keadaan sekolah dalam sarpras), dan faktor lingkungan (keluarga dan masyarakat sekitar). Selain itu juga faktor penghambat yang rata-rata disetiap sekolah diantaranya media pembelajaran yang jumlahnya terbatas, waktu yang sedikit dalam melangsungkan kegiatan proses belajar mengajar Al-quran. ${ }^{17}$

Faktor utama kesulitan membaca alQur'an dianataranya adanya anggapan bahwa huruf arab itu sulit untuk dipelajari dan sangat asing bagi mereka. Dengan demikian anak berasumsi bahwa belajar menulis huruf-huruf dan membaca alQur'an itu sulit.

Berdasarkan kajian dan analisis maka diperoleh temuan yang mendasar yang

17 Atep Supardan, Upaya Guru Pendidikan Agama Islam Dan Budi Pekerti Dalam Meningkatkan Kemampuan Baca Alquran Siswa Kelas V Di Sdn Gadog 01 Kampung Nambo Desa Sukajaya Kabupaten Bogor, Prosiding Al Hidayah Pendidikan Agama Islam, 227. 
dikategorikan sebagai faktor penunjang dalam keberhasilan dan ketuntasan pembelajaran al-Qur'an di kecamatan cigudeg kabupaten Bogor. Adapun faktor-faktor eksternal siswa yaitu:

Pertama, sarana belajar mengajar yang kurang memadai dan tidak merata. Alat belajar seperti buku referensi, juz amma dan buku-buku pedoman yang digunakan sebagai penunjang keberhasilan pembelajaran baca tulis al-Qur'an masih sangat minim disekolah.

Kedua, tidak adanya papan ajakan atau poster-poster kampanye ajakan yang menarik untuk membaca al-Qur'an di kelas dan area sekolah. Biasanya disekolah-sekolah ada kata-kata Mutiara yang gunanya untuk mengingatkan siswa secara tidak langsung yang ditempel.

Ketiga, terbatasnya waktu yang tersedia sehingga pembelajaran kurang maksimal, dengan waktu yang terbatas akan memberikan dampak kepada siswa, karena membaca dan menulis al-Qur'an membutuhkan kesabaran yang dimiliki oleh siswa.

Keempat, terbatasnya dana yang dimiliki oleh setiap sekolah sehingga belum maksimal dalam penyediaan alat peraga, media pembelajaran dan sarana prasarana yang lain untuk menunjang keberhasilan pembelajaran.

Kelimam, metode pembelajaran yang digunakan masih monoton sehingga kurang menarik perhatian siswa. Hal ini dikarenakan jumlah guru PNS PAI yang ada dikecamatan Cigudeg hanya 9 orang dari 55 sekolah. Dengan demikian terdapat 46 sekolah yang tidak ada guru agamanya dan pembelajaran agama disampaikan oleh guru kelas masingmasing.

Keenam, kurangnya pengawasan, seharusnya pengawas melakukan monitoring kesetiap sekolah guna kelancaran proses pembelajaran dan memecahkan kendala yang dihadapi oleh guru. Selain itu juga kurangnya ketegasan kepala sekolah dalam implementasi metode Tarsana kepada guruguru. Padahal setiap sekolah mengirimkan utusannya untuk mengikuti bimtek metode Tarsana.

Berdasarkan hasil analisis ada beberapa factor internal yang dimiliki oleh siswa sehingga menyebabkan mereka ketidakmampuan dalam menulis dan membaca al-Qur'an diantaranya: (1) Minat siswa yang rendah sehingga mereka kurang menyukai menulis huruf hijaiyah dan berdampak kepada penurunan membaca alQur'an; (2) Perhatian orang tua kepada anaknya yang begitu minim; (3) Motivasi yang minim dalam membaca dan menulis. Ini merupakan salah satu peranan orang tua agar selalu mendorong putra putrinya untuk belajar dengan baik dan tekun. Seseorang yang memiliki motivasi belajar tinggi maka memiliki minat yang tinggi pula untuk selalu berusaha dengan gigih percaya diri agar bisa mencapai apa yang diinginkan walaupun mengalami benyaknya hambatan dalam meraihnya. ${ }^{18}$ Selain itu juga orang tua memberikan pengawasan kepada anakanaknya agar tidak membebaskan anakanaknya bermain gadget atau bermain yang tidak memberikan efek positif.

\section{KESIMPULAN}

Metode Tarsana sangat berhasil dan memberikan kontribusi besar untuk meningkatkan pemahaman dan kualitas bacaan al-Qur'an siswa. selain itu juga bahwa metode Tarsana bisa dipakai oleh semua kalangan generasi penerus Islam untuk belajar membaca al-Qur'an dengan mudah dan menyenangkan. Oleh karena itu, penga-

18 Eni Zulaiha dan Busro, Ekses Ketidaktuntasan Pembelajaran Baca Tulis Alquran terbadap Peningkatan Kuantitas Buta Huruf Arab di Kalangan Pelajar SMA/SMK Umum di Kota Bandung, Jurnal Studi Alquran dan Hadis, 4, (2020), 270. 
jaran dalam Islam berpusat pada hati yang hakikatnya bersifat lembut dan amat sensitif serta mudah dipengaruhi oleh sifat mahmudah dan mazmumah. Metode Tarsana lebih menekankan pada penyeimbangan penggunanan otak kiri dan kanan. Dengan begitu, para siswa akan lebih cepat memahami dan menghafal huruf-huruf hijaiyah dan sekaligus belajar membaca Al-Qur'an dengan lagu sesuai dengan kaidah ilmu tajwid.[]

\section{DAFTAR PUSTAKA}

Ainatu Masrurin. (2019). Resepsi Alquran Dalam Tradisi Pesantren Di Indonesia (Studi Kajian Nagham Alquran Di Pondok Pesantren Tarbitayul Quran Ngadiluweh Kediri). Al-Bayan: Jurnal Studi Ilmu Al-Qur'an Dan Tafsir, 3(2), 101-118. https://doi.org/10.15575/albayan.v3i2.3202

Al-Imam Abu Zakaria Yahya bin Syaraf anNawawi. (1999). Riyadhus Sholibin (A. Sunarto (ed.)). Pustaka Amani.

Aminullah, M. (2017). Nagham Al-Qur' an

Dalam Masyarakat Bima. Annual Conference for Muslim Scholars Kopertais Wilayah IV Surabaya, 110, 535-542. \%0Aproceedings ancoms 2017 nagham al-qur'an dalam ...proceedings.kopertais4.or.id

Arsyadani, Q. (2016). Qiraah Alquran Dengan Nagham Ajam - Lagam Jawa; Kasus Isra' Mi'raj di Istana Negara, Jum'at, 15 Mei 2015. SALAM: Jurnal Sosial Dan Budaya Syar-I, 3(1), 93-108. https://doi.org/10.15408/sjsbs.v3i1.33 20

Atep, S., Rahendra, M., \& Unang, W. (n.d.). Upaya Guru Pendidikan Agama Islam Dan Budi Pekerti Dalam Meningkatkan Kemampuan Baca Alquran Desa Sukajaya Kabupaten Bogor. 1, 225-235.

Busro, B. (2020). Ekses Ketidaktuntasan
Pembelajaran Baca Tulis Alquran terhadap Peningkatan Kuantitas Buta Huruf Arab di Kalangan Pelajar SMA / SMK Umum di Kota Bandung. 4, 259-274. https://doi.org/10.29240/alquds.v4i2. 1770

Kurnia, K. (2020). Gawat, 53,57 Persen Muslim Indonesia Belum Bisa Baca Alquran. Galamedia News. https://galamedia.pikiranrakyat.com/news/pr-35554401/gawat53- 57-persen-muslim-indonesiabelum-bisa-baca-alquran

Mustaqim, S. (2005). Bimbingan Belajar Membaca Al-Qur'an TARSANA. CV. Mahardhika.

Novita Intan. (2018). 65 Persen Masyarakat Indonesia Buta Huruf Alquran. Republika News.

https://republika.co.id/berita/duniaislam/islamnusantara/18/01/17/p2oodi396-65persen-masyarakat-indonesia-butahuruf-alquran

Ramayulis. (2004). Ilmu Pendidikan Islam. Kalam Mulia.

Ratna Puspita. (20119). Disdik Bogor Rencanakan Program Baca Tulis Alquran. https://www.republika.co.id/berita/du nia-

islam/wakaf/pn2hsp423/nasional/jab odetabek-

nasional/19/02/10/pmpsza428-disdikbogor-rencanakan-program-baca-tulisalquran

Sadiah, Maya, R., \& Wahidin, U. (2018). Implementasi Model Pembelajaran dalam Pemberantasan Buta Huruf AlQuran di Majelis Taklim Nurul Hikmah Kampung Situ Uncal Desa Purwasari Kecamatan Dramaga Kabupaten Madiun. Prosa PAI (Prosiding Al Hidayab: Pendidikan Agama Islam), 118.

Syafril, S., \& Yaumas, N. E. (2012). 
Penggunaan Metode Tartil dalam Meningkatkan Kemampuan Membaca al- Qur'an Mahasiswa IAIN Raden Intan Lampung Indonesia. Jurnal Pendidikan. Artikel Seminar International. Johor. 2012 